\title{
Do Teachers Influence High School Students' Creativity? The Experience of University Students in The Bahamas
}

\author{
William J. Fielding \\ Pandora Johnson \\ University of The Bahamas
}

\begin{abstract}
This paper identifies linkages between the experiences of high school students in The Bahamas and their creativity. University students were asked to reflect on their time in high school and recall how their teachers responded to their expressions of creativity demonstrated in their responses to questions, solutions to problems and public contributions to discussions and debate. Of 640 participants, almost $90 \%$ thought that authority figures influenced their creativity, and not necessarily in a positive direction. Around $25 \%$ of the participants claimed not to have offered "bright" ideas in class for fear of being ridiculed. Students from public schools had lower selfreported creativity scores than those from private schools. Students from homes associated with domestic violence were at a higher risk of reporting negative teacher responses to their creativity ("bright ideas") than those students from other homes.
\end{abstract}

\section{Introduction}

Creativity is essential for national development. Without divergent thinking, new ideas do not arise; without new ideas, a country will not demonstrate its own independent thought and eventually it will lose its individuality, fail to diversify and grow its economy and will limit social progress. The importance of creativity in the region has been stressed by, among others, the United Nations Development Programme (2012). Further, "skills like creativity, flexibility and problems solving, [are] skills that are coming more in demand in the knowledge economy" (United Nations System Task Team on the Post-2015 UN Development Agenda, 2015, p. 5). International observations aside, Brent Dean, a former editor of the Nassau Guardian, sounded the alarm for The Bahamas. Drawing attention to the relationship between creativity and the stagnation which characterizes the Bahamian economy, Dean argued, "we should recruit productive types from around the world to boost population, drive innovation" (Dean, 2018).

Text books used in support of the curriculum in teacher education programmes demonstrate the importance of nurturing the thinking skills of students. One such text, Teaching for Thoughtfulness: Classroom Strategies to Enhance Intellectual Development (Barell, 1995), presents strategies for teaching students about the nature of thinking, reflection and problem solving with an emphasis on creating a climate or classroom environment in which students feel invited to think productively. Research endorses the effects of positive student-teacher interactions to influence student outcomes (MacSuga-Gage \& Simonsen, 2015). While school teachers are expected to encourage pupils to "think

@W.J. Fielding \& P. Johnson, 2019. Journal compilation@International Journal of Bahamian Studies, 2019 https://doi.org/10.15362/ijbs.v25i0.341 
outside of the box" (Pearson, 2018) and engage in divergent thinking (Goodman, 2015), for this strategy to be successful, teachers who are advised to see teaching as modelling behaviour must think outside of the "teacher's box" (Darn, 2006). Teachers also have to be purposeful as to how they respond to children's creativity if they are to be successful in nurturing creativity (Geist \& Hohn, 2009). In order for initiatives to be successful, school management must also be supportive of them, but where rote learning is prevalent, this becomes a barrier to success (Changwong, Sukkamart, \& Sisan, 2018).

Recognition of the importance of creative thinking has led to curriculum changes in places such as Singapore (Tan, 2006). Creativity, Noddings (2013) suggested, can be undermined when teachers feel obliged to follow rigidly a standardised curriculum. A standardised curriculum is also a feature of the Bahamian education system. In light of Noddings' perspective, this characteristic may pose a further threat to the nurturing of creativity in children.

Children spend most of their time either in school or at home. Both places can provide experiences which may encourage or discourage creativity. However, the focus of this study examined how experiences at school might be linked with creativity. As outlined above, it is apparent that social norms and the education system have considerable potential to influence creativity. More recently, creativity in schools has been revisited in an attempt to update the common understanding of creativity (Perry \& Collier, 2018).

In societies where children are expected to be well-behaved and/or conform to social norms, creativity and divergent thinking can be stifled by the prevailing culture (Rudowicz, 2003; Fang, Xu, Grant, Stronge,
\& Ward, 2016). This concern is longstanding, as seen from a study carried out in Turkey by Guncer and Oral (1993). In The Bahamas, child rearing practices often rely on the use of corporal punishment to ensure that children behave within accepted norms, both at home and in society (Carroll, Fielding, Brennen, \& Hutcheson, 2016). Moreover, corporal punishment is also permitted in schools, under particular conditions (Johnson, 2016), to ensure students are compliant. According to media reports, such punishment might be considered abuse (Turnquest, 2018). Given the concern in Jamaica about the use of violence in rearing children (Smith \& Mosby, 2003), it is clear that Bahamian cultural norms run the risk of curtailing creativity by discouraging divergent thought and action. Rather than managing this divergence, to actively discourage it is unlikely to be in the best interests of society as a whole.

Creativity is considered to be multidimensional resulting in various attempts to define it. Villalba (2008) provides an overview of creativity: creativity is viewed as involving the imagination as it requires some degree of originality, the result has a purpose and involves an evaluation of the idea. Villalba also notes that risk taking can also be part of a creative mind which can be appreciated by some people having an entrepreneurial mind, that is, those who are willing to action their creative idea knowing that it may not be certain of success.

For the purposes of this study, creativity is viewed as being positive engagement in activities which span the traditionally creative areas, such as the arts, to daily problem solving, this in opposition to the creativity attributed to criminals (Eisenman, 2008). While creativity may be difficult to define and measure (Boden, 1994), people 
recognise it when they see it (Foster, 2015). For this reason, this study used self-reported perceptions of creativity rather than imposing a defined measure of creativity. While self-reporting might lead to optimistic assessments of creativity, provided the overall bias is similar across all respondents, differences in perceived creativity would be appropriately identified even if the mean scores are biased.

\section{Methodology}

An internet study was devised which combined questions from Kaufman (2012) on creativity with Sherin's HITS index (Sherin, Sinacore, Li, Zitter, \& Shakil, 1998), to determine whether domestic violence occurred in the students' homes, with questions devised by a group of University of The Bahamas students. This latter group of questions related to how teachers responded to the creativity of high school students. The target population was university students aged 18-24 years. They were recruited through a snowball technique via social media groups of university students enrolled in a research methods class. Participants, current university students, were asked to recall their experiences in high school. Students in the Spring 2018 SOS 200 research class were required to solicit the participation of 25 students (23 using the online survey and two participants in person) as part of their class work. The anticipated sample size was 475 .

Students were also asked to engage two students in qualitative interviews on the reactions of their teachers to their creative/divergent thinking. A selection of quotations from the interviews is used to illustrate the quantitative data. The 50 questions concerning creativity, taken from Kaufman (2012), were self-reported and scored 0 if the participant did not do an activity at all and 5 if they claimed that they were very creative with respect to the activity. Consequently, the maximum creativity score was 250 .

Readers should note that respondents are university students, representing that subset of high school students who have successfully navigated the school curriculum in the sense that they have proceeded to university. Consequently, their answers may not reflect what might be found in students who did not continue their education in an academic setting. However, the responses are important in that these students will be expected to ultimately occupy influential positions in society.

\section{Results}

\section{Demographics}

Six hundred and forty students participated in the study. However, some respondents did not complete their surveys; consequently, this figure represents the maximum sample size. The majority of respondents were female $(69.3 \%$ of 573$)$, which is consistent with the composition of the student population. The majority of participants had completed most of their schooling in the public school system, $53.5 \%$ of 572 replies.

Male respondents were more likely than female respondents to have been physically disciplined at school (Odds Ratio (OR) = 1.26, 95\% CL [1.13-1.42], $n=573)$. Students at public schools were more likely than those in private schools to have been physically disciplined $(\mathrm{OR}=1.62,95 \% \mathrm{CL}$ [1.14-2.29], $n=572)$.

Most respondents thought of themselves as the leader in a group $(74.9 \%$ of 573 responses), while $15.3 \%$ (of 570) thought of themselves as followers in a group. While $47.9 \%$ (of 568 responses) thought of themselves as being introverts, $24.5 \%$ were unsure. The majority of participants $(60.7 \%$ of 573 responses) demonstrated an entrepreneurial spirit by indicating that they would invest $\$ 1$ million in their own 
company or a "start-up" rather than put that money in the bank. Overall, $76.4 \%$ (of 571 responses) considered themselves as "creative". There was general agreement that those in authority over students influenced their creativity ( $89.6 \%$ of 519 responses).

\section{Actions of teachers}

Not all students reported that their teachers encouraged them to think outside of the box. Teachers were also reported to have treated students in ways which may not have encouraged their participation in class or creativity. In particular, about a quarter of the participants suggested that their teachers could not manage divergent contributions given in class, Table 1.

Table 1

Actions reported by participants of student contributions to class. Percentages within actions.

\begin{tabular}{lcccc}
\hline Action of teacher/student & Yes & No & $\begin{array}{l}\text { Cannot } \\
\text { remember }\end{array}$ & $n$ \\
\hline Ever praised student publicly for a different idea (a "bright idea") & 71.4 & 17.8 & 10.8 & 574 \\
Wanted student to think "outside of the box" & 67.9 & 24.4 & 7.6 & 577 \\
$\begin{array}{l}\text { Fear of embarrassment prevented student from answering } \\
\text { questions in class }\end{array}$ & 62.2 & 32.9 & 4.9 & 574 \\
$\begin{array}{l}\text { Publicly ridiculed for the answer student provided to an } \\
\text { assignment }\end{array}$ & 29.4 & 61.4 & 9.2 & 575 \\
$\begin{array}{l}\text { Student verbally put down by teacher for expressing a difference } \\
\text { in opinion }\end{array}$ & 28.1 & 61.2 & 10.7 & 572 \\
$\begin{array}{l}\text { Punished student for not providing the answer required by the } \\
\text { teacher }\end{array}$ & 26.8 & 63.2 & 9.9 & 574 \\
$\begin{array}{l}\text { Publicly ridiculed student for giving a different answer to the rest } \\
\text { of the class }\end{array}$ & 24.2 & 64.9 & 11.0 & 575 \\
\hline
\end{tabular}

One participant stated:

I would say that I was creative all through school but I was most creative when I was a child from primary school days because we were allowed to do so many things, and I didn't even realise that it was creativity at that stage. I just thought I was having fun. As I grew older, I would say that it was more restricted because you know in high school and junior school they try to control the environment more, even though they controlled in primary school but because you were a child they would allow you to play and do a lot of things. But in junior and high school they are more serious and they focus you on the real world but they don't focus on you being free and being a creative. So I would say in primary school it was much easier but in junior school and high school it wasn't so much, it was very restrictive in saying hey this is the real world and you can't do this there and you can't really have fun in the real world, that how I took it because it was really boring.

About one in four participants claimed not to have offered good ideas in class (Table 2). This suggests that these students may not have been engaged with the school curriculum and were not encouraged by the teacher to think of ideas to share with classmates. About $15 \%$ of respondents thought that their good ideas had been ignored or that they had been "put down" in 
response to their idea - actions which could discourage students from engaging in class activities.

Table 2

Reaction of the teacher to a respondent's good idea.

\begin{tabular}{lc}
\hline & $\%$ \\
\hline Praise you & 59.8 \\
Put you down & 4.6 \\
lgnore you & 9.7 \\
I never offered ideas in class & 26 \\
\hline$n$ & 569 \\
\hline
\end{tabular}

However, positive reactions to creativity can further engage students to be creative. According to one respondent, "I had very supportive teacher[s] who pushed us to be creative throughout school, while providing the right environment for that expression of creativity. If anything I was forced to be creative in the type of environment they created."

The reactions of teachers to a "good idea" from the student were associated with other actions of the teacher towards the student (Table 3). These associations suggest that some teachers' actions can reinforce each other in ways which may not always be conducive to encouraging students' "good" ideas. The reactions of teachers may also indicate that they are unwilling to encourage students to offer divergent thoughts.

Table 3

Reaction of the teacher to a student's good idea and other actions in class (Percentages within action of teacher).

\begin{tabular}{|c|c|c|c|c|c|c|}
\hline & & & & & & $x^{2}$ \\
\hline Action of teacher & & Praise you & Put you down & Ignore you & $\begin{array}{l}\text { I never offered } \\
\text { ideas in class }\end{array}$ & $p$ \\
\hline \multirow{3}{*}{$\begin{array}{l}\text { Verbally put } \\
\text { down for } \\
\text { expressing a } \\
\text { difference in } \\
\text { opinion? }\end{array}$} & Yes & $48.8 \%$ & $13.1 \%$ & $20 \%$ & $18.1 \%$ & \\
\hline & No & $64.7 \%$ & $0.9 \%$ & $5.5 \%$ & $29.0 \%$ & \\
\hline & $\begin{array}{l}\text { Cannot } \\
\text { remember }\end{array}$ & $58.6 \%$ & $3.4 \%$ & $6.9 \%$ & $31 \%$ & $<.001$ \\
\hline \multirow{3}{*}{$\begin{array}{l}\text { Praised publicly } \\
\text { for a different } \\
\text { idea (a "bright } \\
\text { idea")? }\end{array}$} & Yes & $69.4 \%$ & $3.7 \%$ & $7.8 \%$ & $19.1 \%$ & \\
\hline & No & $31 \%$ & $9 \%$ & $18 \%$ & $42 \%$ & \\
\hline & $\begin{array}{l}\text { Cannot } \\
\text { remember }\end{array}$ & $41.7 \%$ & $3.3 \%$ & $8.3 \%$ & $46.7 \%$ & $<.001$ \\
\hline \multirow{3}{*}{$\begin{array}{l}\text { Publicly ridiculed } \\
\text { for giving a } \\
\text { different answer } \\
\text { to the rest of the } \\
\text { class? }\end{array}$} & Yes & $51.1 \%$ & $12.2 \%$ & $18.0 \%$ & $18.7 \%$ & \\
\hline & No & $63.7 \%$ & $2.2 \%$ & $6.8 \%$ & $27.4 \%$ & \\
\hline & $\begin{array}{l}\text { Cannot } \\
\text { remember }\end{array}$ & $55.7 \%$ & $1.6 \%$ & $8.2 \%$ & $34.4 \%$ & $<.001$ \\
\hline \multirow{3}{*}{$\begin{array}{l}\text { Punished for not } \\
\text { providing the } \\
\text { answer required } \\
\text { by the teacher? }\end{array}$} & Yes & $50.6 \%$ & $7.8 \%$ & $17.5 \%$ & $24 \%$ & \\
\hline & No & $64.6 \%$ & $3.1 \%$ & $5.6 \%$ & $26.7 \%$ & \\
\hline & $\begin{array}{l}\text { Cannot } \\
\text { remember }\end{array}$ & $51.9 \%$ & $5.6 \%$ & $14.8 \%$ & $27.8 \%$ & $<.001$ \\
\hline \multirow{3}{*}{$\begin{array}{l}\text { Publicly ridiculed } \\
\text { for the answer } \\
\text { you provided to } \\
\text { an assignment? }\end{array}$} & Yes & $55 \%$ & $8.3 \%$ & $15.4 \%$ & $21.3 \%$ & \\
\hline & No & $62.2 \%$ & $3.2 \%$ & $6.3 \%$ & $28.4 \%$ & \\
\hline & $\begin{array}{l}\text { Cannot } \\
\text { remember }\end{array}$ & $58 \%$ & $2 \%$ & $14 \%$ & $26 \%$ & .002 \\
\hline
\end{tabular}


In their efforts to focus on the recognised "correct" answer, teachers may stifle creativity:

When I was in high school, my English class would have discussions about various books, politics and history. One day, we were discussing the use of the word nigger. I was the only one who disagreed on her view and instead of justifying why her view was right, she called me stupid.

I once answered a question wrong and the teacher mocked me for it. After the class had laughed along with her, I felt a bit angry and embarrassed. I tried to stay as quiet as possible and stopped trying to answer questions. I didn't want to experience that again. Although teachers say there is no dumb question, they say otherwise after you talk.

Participants from the public school system were more likely to have been physically disciplined at school than those who attended private schools $(\mathrm{OR}=1.62,95 \%$
CL [1.14-2.29], $n=572$ ). This might suggest that behaviour which disrupts learning is more of an influence in the lives of public rather than private school students. Alternatively, it may mean that teachers in public schools may have a greater focus on forcing students to conform to classroom expectations, rather than finding ways which channel disruptive actions to positive divergent outcomes. However, the behaviour of teachers in both private and public school systems was similar $(p>.05)$ with respect to the items in Table 1.

Students who emerged from homes in which domestic violence occurred were more likely to suffer behaviours of concern from teachers, Table 4 . Table 4 suggests that teachers may be reinforcing some of the concerning behaviours to which students in homes with domestic violence may be expected to suffer, such as being "put down". From the student standpoint, students from homes with domestic violence may feel that they are moving from one negative space to another.

Table 4

Association between domestic violence in the homes of students and actions reported by participants of student contributions to class. Percentages reporting this action.

\begin{tabular}{|c|c|c|c|}
\hline \multirow[b]{2}{*}{ Action of teacher/student } & \multicolumn{2}{|c|}{ Domestic violence: } & \multirow{2}{*}{$\begin{array}{l}x^{2} \\
p=\end{array}$} \\
\hline & Absent & Present & \\
\hline Ever praised student publicly for a different idea (a "bright idea") & 80.4 & 79.5 & .825 \\
\hline Wanted student to think "outside of the box" & 77.2 & 69.4 & .049 \\
\hline $\begin{array}{l}\text { Fear of embarrassment prevented student from answering } \\
\text { questions in class }\end{array}$ & 60.4 & 70.2 & .019 \\
\hline Publicly ridiculed for the answer student provided to an assignment & 26.0 & 38.8 & .002 \\
\hline $\begin{array}{l}\text { Student verbally put down by teacher for expressing a difference in } \\
\text { opinion }\end{array}$ & 26.2 & 36.7 & .007 \\
\hline $\begin{array}{l}\text { Punished student for not providing the answer required by the } \\
\text { teacher }\end{array}$ & 22.8 & 36.1 & .001 \\
\hline $\begin{array}{l}\text { Publicly ridiculed student for giving a different answer to the rest of } \\
\text { the class }\end{array}$ & 20.6 & 33.0 & .002 \\
\hline
\end{tabular}


While domestic violence was not associated with the participants' views of being a leader, it was with regard to being a "follower" (Table 5).

Table 5

Association between domestic violence in the student's home and the student's perception of their leadership.

\begin{tabular}{lccc}
\hline & \multicolumn{2}{c}{ Domestic violence } & $X^{2}$ \\
$\begin{array}{l}\text { Percentage } \\
\text { indicating this } \\
\text { aspect: }\end{array}$ & Absent & Present & $p=$ \\
\hline $\begin{array}{l}\text { A leader in a } \\
\text { group }\end{array}$ & 78.1 & 71.2 & .124 \\
$\begin{array}{l}\text { Not a follower in } \\
\text { a group }\end{array}$ & 73.4 & 62.4 & .003 \\
\hline
\end{tabular}

However, despite the lack of statistical significance, the percentage of those who emerged from homes where domestic violence was absent and considered themselves as leaders was slightly higher than the percentage emerging from homes with domestic violence. When looking at these two questions together, the impact of domestic violence on leadership becomes apparent.
The students' perception of teachers to have an influence on their creativity was related to their creativity score (analysis of variance, $d f=3,476, p<.001$ ), with those students with the lowest creativity scores having the perceptions that teachers did not influence their creativity (see Table 6).

Table 6

Creativity score of participants' reaction to teacher influence on creativity.

\begin{tabular}{lll}
\hline $\begin{array}{l}\text { Teachers can influence } \\
\text { a student's creativity: }\end{array}$ & Mean & SE \\
\hline Yes, positively & 146.1 & 2.70 \\
Yes, negatively & 141.9 & 3.08 \\
Not sure & 130.4 & 2.82 \\
No & 121.9 & 6.92 \\
\hline
\end{tabular}

Teachers did not necessarily respond to the "bright" ideas which students offered in ways which might have encouraged further creativity or divergent thoughts. Those who were put down or ignored when they offered a good idea were more unlikely to have been praised $\left(\chi^{2}=64.4, d f=6, n=568, p<.001\right.$, Table 7).

Table 7

Public praise by the teacher for a different idea and the teacher's response to what the participant thought was a good idea.

\begin{tabular}{lcccc}
\hline $\begin{array}{l}\text { Were you ever praised } \\
\text { publicly by a teacher for a } \\
\text { different idea (a "bright idea")? }\end{array}$ & $\begin{array}{l}\text { If you came up with what you thought was a good idea in class, how } \\
\text { did the teacher respond? } \\
\text { Praise you }\end{array}$ & Put you down & Ignore you & $\begin{array}{l}\text { I never offered ideas in } \\
\text { class }\end{array}$ \\
\hline Cannot remember & $7.4 \%$ & $7.7 \%$ & $9.1 \%$ & $18.9 \%$ \\
No & $9.1 \%$ & $34.6 \%$ & $32.7 \%$ & $28.4 \%$ \\
Yes & $83.5 \%$ & $57.7 \%$ & $58.2 \%$ & $52.7 \%$ \\
\hline$n=$ & 339 & 26 & 55 & 148 \\
\hline
\end{tabular}

Different opinions did not appear to be necessarily welcomed or well managed by teachers. Even students who were praised for coming up with what they thought was a 
good idea could also be put down by the teacher for expressing a difference of opinion (see Table $8 ; \chi^{2}=70.7, d f=6, n=$ $566, p<.001)$. A difference of opinion could be a part of original thought, so some teachers may be responding in ways which fail to promote creativity.

Table 8

Association between participants' providing a good idea and teachers' reaction and verbal response to differing opinions.

\begin{tabular}{ccccc}
\hline $\begin{array}{l}\text { Verbally put down by } \\
\text { teacher for expressing a } \\
\text { difference in opinion? }\end{array}$ & $\begin{array}{l}\text { If you came up with what you thought was a good idea in class, how did the } \\
\text { teacher respond? } \\
\text { Praise you }\end{array}$ & Put you down & Ignore you & I never offered ideas in class \\
\hline Cannot remember & $10.1 \%$ & $7.7 \%$ & $7.3 \%$ & $12.2 \%$ \\
No & $66.8 \%$ & $11.5 \%$ & $34.5 \%$ & $68.2 \%$ \\
Yes & $23.1 \%$ & $80.8 \%$ & $58.2 \%$ & $19.6 \%$ \\
\hline$n$ & 337 & 26 & 55 & 148 \\
\hline
\end{tabular}

Teachers' reactions to a good idea offered by participants was associated with the entrepreneurial outlook of participants (see Table 9; $\chi^{2}=21.7, d f=6, n=565, p=.001$ ). The encouragement offered to students with an entrepreneurial spirit indicates that teachers may have a role to play which can encourage or discourage students from engaging in creative activities with ambiguous (risky) results.

Table 9

Teacher reaction to a good idea offered by participants and entrepreneurial outlook of participants.

\begin{tabular}{cccccc}
\hline & \multicolumn{3}{c}{ If you came up with what you thought was a good idea in class, how did } \\
& $\begin{array}{l}\text { the teacher respond? } \\
\text { Praise you }\end{array}$ & Put you down & lgnore you & I never offered ideas in class & $n$ \\
\hline $\begin{array}{c}\text { Putting it in the bank } \\
\begin{array}{c}\text { By starting your own } \\
\text { new company or }\end{array}\end{array}$ & $55.4 \%$ & $2.1 \%$ & $9.3 \%$ & $33.2 \%$ & 183 \\
$\begin{array}{c}\text { investing in a "start-up" } \\
\text { No idea }\end{array}$ & $63.8 \%$ & $5.8 \%$ & $9.9 \%$ & $20.4 \%$ & 343 \\
\hline
\end{tabular}

The behaviour of teachers was associated with the type of home from which the student emerged. Table 10 indicates how students from homes in which incidents of domestic violence occurred are more at risk of having negative experiences in class than those who did not come from such homes. This suggests that teachers are providing an atmosphere in class which reinforces the negative experiences to which children from homes with domestic violence can expect to be subjected. Table 10 suggests a link between the reactions of teachers towards participants' good ideas and the participant's self-assessment of their creativity $\left(\chi^{2}=31.6\right.$, $d f=3, n=565, \mathrm{p}<.001)$. This suggests that the teacher's action may influence the creative self-confidence of respondents. 
Table 10

Teacher reaction to a good idea offered by participants by participants' perception of their creativity.

\begin{tabular}{|c|c|c|c|c|c|}
\hline \multirow{2}{*}{$\begin{array}{l}\text { I consider myself } \\
\text { as a creative } \\
\text { person }\end{array}$} & \multicolumn{4}{|c|}{$\begin{array}{l}\text { If you came up with what you thought was a good idea in class, how did the } \\
\text { teacher respond? }\end{array}$} & \multirow[t]{2}{*}{$n$} \\
\hline & Praise you & Put you down & Ignore you & I never offered ideas in class & \\
\hline Yes & $64.5 \%$ & $4.9 \%$ & $10.2 \%$ & $20.4 \%$ & 431 \\
\hline No & $43.3 \%$ & $3.7 \%$ & $8.2 \%$ & $44.8 \%$ & 134 \\
\hline
\end{tabular}

Participants who emerged from homes within which incidents of domestic violence occurred, reported different experiences with their teachers than those who did not (see Table 11). Again, these experiences might be considered to offer less encouragement to those children who may need a supportive environment at school to offset the negativity of their home space.

Table 11

Percentage of participants reporting this aspect within the presence or absence of domestic violence in their homes.

\begin{tabular}{lccc}
\hline & Domestic violence & $x^{2}$ \\
& No & Yes & $p=$ \\
\hline $\begin{array}{l}\text { Percentage indicating this aspect: } \\
\begin{array}{l}\text { Were you ever praised publicly by a teacher for a different idea (a } \\
\text { "bright idea")? }\end{array}\end{array}$ 69.2 & 73.2 & .064 \\
$\begin{array}{l}\text { Were you punished by a teacher for not providing the answer required } \\
\text { by the teacher? }\end{array}$ & 20.5 & 32.6 & .004 \\
$\begin{array}{l}\text { Were you publicly ridiculed by a teacher for the answer you provided to } \\
\text { an assignment? }\end{array}$ & 23.6 & 35.2 & .008 \\
$\begin{array}{l}\text { Were you publicly ridiculed by a teacher for giving a different answer to } \\
\text { the rest of the class? }\end{array}$ & 18.2 & 29.6 & .007 \\
$\begin{array}{l}\text { Did your fear of embarrassment prevent you from answering questions } \\
\text { in class? }\end{array}$ & 56.1 & 68.3 & .003 \\
$\begin{array}{l}\text { Do you recall being verbally put down by your teacher for expressing a } \\
\text { difference in opinion? }\end{array}$ & 23.2 & 33.0 & .035 \\
\hline
\end{tabular}

\section{Factors influencing creativity}

Cronbach's alpha for the creativity score was 0.928, which demonstrates good internal reliability of the scale. The overall scores of creativity associated with each item in the creativity scale are given in Table 12. There was variability in the levels of creativity. The overall mean creativity score was 2.79. In Table 12, a one sample t-test was used to identify those items of creativity which were significantly different to 2.79 , or different to the overall mean. In the absence of comparative data, the assessment against the overall mean enables us to identify areas of more and less perceived creativity which allows for a discussion on those areas where the level of creativity may be considered a cause for concern. Table 12 indicates that while there are a number of creative activities at which students score over three, others such as carving, pottery, writing a computer programme, examining how a machine works, or making a machine, are areas in which students exhibit relatively limited creative engagement. 
Table 12

Mean creativity score, $p$ values indicate those significantly different to the overall creativity score.

\begin{tabular}{|c|c|c|c|}
\hline Aspect of creativity & Mean & SE & $p=$ \\
\hline Writing a poem & 2.81 & 0.06 & .723 \\
\hline Making up rhymes & 2.74 & 0.06 & .362 \\
\hline Writing a nonfiction article for a newspaper, etc. & 2.09 & 0.07 & $<.001$ \\
\hline Making up lyrics for a song & 2.74 & 0.06 & .470 \\
\hline Writing a letter to an editor & 2.32 & 0.07 & $<.001$ \\
\hline Thinking of a good metaphor, simile or analogy & 3.09 & 0.06 & $<.001$ \\
\hline Finding something fun to do when you have no money & 3.71 & 0.05 & $<.001$ \\
\hline Composing an original song & 2.17 & 0.07 & $<.001$ \\
\hline Making up dance moves & 2.45 & 0.07 & $<.001$ \\
\hline Shooting a fun video to put on YouTube or similar & 2.10 & 0.07 & $<.001$ \\
\hline Singing in harmony & 2.59 & 0.07 & .003 \\
\hline Playing music in public & 2.77 & 0.07 & .784 \\
\hline Acting in a play & 2.81 & 0.07 & .760 \\
\hline Entertaining a small child & 3.89 & 0.05 & $<.001$ \\
\hline Helping others cope with a 'difficult situation' & 3.92 & 0.05 & $<.001$ \\
\hline Teaching someone how to do something & 3.85 & 0.04 & $<.001$ \\
\hline Planning a trip or event with friends that meets everyone's needs & 3.41 & 0.06 & $<.001$ \\
\hline Mediating a dispute or argument between two friends & 3.48 & 0.05 & $<.001$ \\
\hline Getting people to feel relaxed and at ease & 3.67 & 0.05 & $<.001$ \\
\hline Decorating a room & 3.40 & 0.06 & $<.001$ \\
\hline Sketching a person or object & 1.91 & 0.07 & $<.001$ \\
\hline Doodling/drawing random or geometric designs & 2.33 & 0.07 & $<.001$ \\
\hline Carving something out of wood or similar material & 1.17 & 0.06 & $<.001$ \\
\hline $\begin{array}{l}\text { Making a scrapbook page (on paper or using software) out of my } \\
\text { photographs }\end{array}$ & 2.16 & 0.07 & $<.001$ \\
\hline Making a sculpture or piece of pottery & 1.16 & 0.06 & $<.001$ \\
\hline Thinking of a new invention & 2.19 & 0.07 & $<.001$ \\
\hline
\end{tabular}




\begin{tabular}{|c|c|c|c|}
\hline Aspect of creativity & Mean & SE & $p=$ \\
\hline Figuring out how to fix a frozen or buggy computer & 2.25 & 0.07 & $<.001$ \\
\hline Writing a computer programme/app & 1.18 & 0.06 & $<.001$ \\
\hline Solving maths puzzles & 2.66 & 0.06 & .042 \\
\hline Taking apart machines and figuring out how they work & 1.72 & 0.07 & $<.001$ \\
\hline Building something mechanical like a robot & 0.97 & 0.06 & $<.001$ \\
\hline Helping to carry out or design a scientific experiment & 2.02 & 0.07 & $<.001$ \\
\hline Designing a way to test an hypothesis & 2.16 & 0.07 & $<.001$ \\
\hline Solving an algebraic or geometric proof & 2.07 & 0.06 & $<.001$ \\
\hline Analysing an argument & 3.45 & 0.05 & $<.001$ \\
\hline Researching a topic using many different types of sources & 3.19 & 0.06 & $<.001$ \\
\hline Comparing two different points of view & 3.55 & 0.05 & $<.001$ \\
\hline Debating a controversial topic from my own perspective & 3.44 & 0.06 & $<.001$ \\
\hline $\begin{array}{l}\text { Gathering the best possible assortment of articles or papers to support a } \\
\text { specific point of view }\end{array}$ & 2.88 & 0.06 & .134 \\
\hline Arguing a side in a debate that I do not personally agree with & 2.91 & 0.06 & .066 \\
\hline Figuring out how to integrate critiques and suggestions while revising work & 2.89 & 0.06 & .095 \\
\hline $\begin{array}{l}\text { Being able to offer constructive feedback based on my own reading of a } \\
\text { paper }\end{array}$ & 3.23 & 0.05 & $<.001$ \\
\hline Coming up with a new way to think about an old debate & 2.83 & 0.06 & .558 \\
\hline Thinking of new ways to help people & 3.69 & 0.05 & $<.001$ \\
\hline Choosing the best solution to a problem & 3.69 & 0.04 & $<.001$ \\
\hline Responding to an issue in a context appropriate way & 3.44 & 0.05 & $<.001$ \\
\hline Understanding how to make myself happy & 3.87 & 0.05 & $<.001$ \\
\hline Being able to work through my personal problems in a healthy way & 3.56 & 0.05 & $<.001$ \\
\hline Analysing the themes in a good book & 2.95 & 0.06 & .009 \\
\hline Burning a CD, or similar, to introduce a friend to new songs & 2.85 & 0.08 & .477 \\
\hline
\end{tabular}

The students' perception as to whether or not they were creative was validated by the overall self-reported creativity score, a score which is not based on one aspect of creativity. Students thinking themselves creative had a significantly higher mean creativity score of 145.1 ( $\mathrm{SE}=1.76)$ compared to those who did not think of themselves as creative, 116.9 ( $\mathrm{SE}=3.20, p$ $<.001)$. Likewise, the students' perception 
of whether or not their teachers thought they were creative was validated by the students' creativity score. Those who were considered creative had a score of 149 ( $\mathrm{SE}=2.10)$, while those who were not, $122.9(\mathrm{SE}=3.02)$ and those who could not remember, 132.1 $(\mathrm{SE}=3.52, p<.001)$. The reaction of the teacher as to what the student thought was a good idea was associated with significantly different creativity scores (analysis of variance, $d f=3,474, p<.001)$. This finding may suggest that teachers may tend to focus their positive responses on the more creative students and so run the risk of not doing enough to draw out or enhance the creative ideas of those who display less creativity or less well formed creative ideas.

Table 13

Participants' creativity score and reaction of teacher to participants' good idea.

\begin{tabular}{lcc}
\hline & Mean & SE \\
\hline Praise you & 147.7 & 1.97 \\
Ignore you & 135.0 & 4.67 \\
Put you down & 132.0 & 8.63 \\
I never offered ideas in & 120.6 & 3.15 \\
\hline
\end{tabular}

Table 14

Creativity scores by first reason stated for being physically punished at school.

\begin{tabular}{lcc}
\hline $\begin{array}{l}\text { Reason for being } \\
\text { disciplined }\end{array}$ & Mean & SE \\
\hline Supplies & 100 & 18.93 \\
Cursing & 123.1 & 8.02 \\
Other & 126.9 & 12.79 \\
Disobedience & 135 & 7.14 \\
Talking & 138.2 & 3.62 \\
Poor grades & 139.5 & 7.53 \\
Fighting & 143 & 6.96 \\
Being rude & 143.7 & 8.44 \\
Back talking & 147.1 & 8.18 \\
Misbehaviour, not specific & 147.5 & 5.31 \\
Being late & 149.8 & 7.57 \\
\hline
\end{tabular}

Although there was not a significant difference $(p>.05)$ in the creativity scores of those students who were and were not physically punished at school (138.3 vs. 140.6), there were differences in the creativity scores with respect to the first reason stated for which the student was punished (analysis of variance $d f=10,254$, $F=1.881, p=.048$, Table 14 ). The fact that the most creative students were disciplined for being late suggests that even these students may not be sufficiently engaged by the school curriculum so as to make them want to get to school on time.

As anticipated from the literature, a link between creativity and entrepreneurship was found with participants who would invest a $\$ 1$ million in either a start-up or their own company having a significantly higher creativity score than those who would put the money in the bank (144.5, $\mathrm{SE}=2.11 c f$. 131.2, $\mathrm{SE}=2.73)$.

Likewise, those who considered themselves leaders in their group had a higher mean creativity score $(144.7, \mathrm{SE}=1.83)$ that those who did not $(118.8, \mathrm{SE}=6.30)$, with those being not sure having a creativity score inbetween these groups, 123, $\mathrm{SE}=3.51$ (analysis of variance, $d f=2,478, \mathrm{~F}=19.4, p$ $<.001)$. Those students who offered ideas in class were more likely to put money in the bank than those who did not $(\mathrm{OR}=1.93$, 95\% CL [1.30-2.88] $n=536)$. Consequently, it can be appreciated that cultivating creativity has the potential to have an impact beyond what happens in an academic setting and an impact on the economic growth of a country.

As seen above, several factors were associated with the creativity scores. A linear regression, with a backward elimination procedure, was done to determine those factors which were significantly related to creativity. This resulted in the analysis of variance table in Table 15. 
Table 15

Analysis of variance of factors having a significant effect on creativity scores.

\begin{tabular}{lcccc}
\hline \multicolumn{1}{c}{ Source } & $d f$ & $M S S$ & $\mathrm{~F}$ & $p$. \\
\hline Where most school years spent & 1 & 4986.69 & 4.16 & .042 \\
Ever praised publicly by a teacher for a different idea (a "bright idea") & 2 & 10751.81 & 8.96 & $<.001$ \\
Felt that your teachers wanted you to think "outside of the box" & 2 & 10998.14 & 9.17 & $<.001$ \\
Residual & 472 & 1199.93 & & \\
\multicolumn{1}{c}{ Total } & 477 & & \\
\hline
\end{tabular}

The adjusted means indicate that creativity scores in public schools are lower than for private schools (128.7, cf 122.2), those students who were praised for their bright idea had higher creativity scores (Praised $=$ 135.9, Not praised, 125.0 and Cannot remember $=115.5)$, and those students who had a teacher who encouraged them to "think outside of the box" had a higher creativity score (135.5) compared those to those who could not remember (109.1), but not those who did not (131.7).

\section{Discussion}

When interpreting these results, it is important to remember that the respondents were current University of The Bahamas students who had recently left high school. They are giving an overall impression of their high school experience which should allow them to reflect on their high school experience at the start of their adult life. Further, the associations demonstrate the "average" picture. This is important to note because creativity is very individual and can be influenced in many ways. Thus, the data only present an overall picture which would not preclude many "exceptions to the rule." Moreover, the associations do not necessarily infer any causation and, in particular, which action may be the cause of another. In this regard, although praise of an idea may be associated with creativity, this study cannot necessarily indicate which comes first: the idea or the praise.
This study supports the view that incidences of violent behaviour occur more often in public schools than in private schools (Johnson, 2016) and that female students are less subjected to physical discipline than male students. ${ }^{1}$ While there was no clear link between physical violence and creativity, how teachers responded to the "bright" ideas of students was linked with creativity. Participants also thought that those in authority could influence their creativity, although the case studies demonstrated that, in some cases, negative actions of teachers actually encouraged students to express their creativity more. What is clear is that students with teachers who encouraged them to "think outside of the box" reported higher creativity scores than those who did not. Associated with this is the need for teachers to provide an atmosphere which encourages creativity. The extended quotation of one participant therefore indicates while there is a complex matrix of forces at play, it is clear that teachers have an important role to play in nurturing student creativity.

Given that around $75 \%$ of the student population in The Bahamas attend public schools (Bahamas Information Services, 2016), the apparent lower creativity in these students compared to private school students

\footnotetext{
1 It is important to note that violence occurs in both public and private schools and both sexes are physically disciplined by school administrators.
} 
is of concern. However, it should be appreciated that this difference in creativity may not reflect weaknesses in the school system but rather the social-economic background of the child.

The socio-economic background has been identified as being important in the case of student performance in national examinations (Collie-Patterson, 2008). If that is the case, then teachers may need to work harder to develop the inherent creativity of students particularly when students may emerge from homes which may not promote their creativity. This matter was noted in Table 4 and would suggest the importance of individual attention for each child so that teachers know and share knowledge about the domestic situation of each child.

The finding that around $25 \%$ of study participants did not offer ideas in class might be viewed as an important concern. Although this study cannot explain why students did not offer ideas in class, those who did not offer ideas in class reported the lowest mean creativity score. What is apparent is that these students would appear not to have been particularly engaged by the school curriculum or how it was presented. Given that this percentage of $25 \%$ is being reported by those students who progressed to university, we can reasonably expect that the corresponding percentage in the wider population of school children would be higher. The association between offering ideas in class and entrepreneurial spirit suggests that failure to engage students in class may have a negative impact on the economic growth of the country. The importance of student engagement in class is well known to be critical to student success (Wang \& Degol, 2014) and lack of engagement, seen in its extreme when students are expelled, is of concern with respect to crime and violence (Fielding,
Ballance, \& Strachan, 2016).

Lack of engagement may explain why those students who were disciplined for violent offences or for being late had higher creativity scores than other students. This reason for being disciplined contrasts with those students who were punished for lack of supplies, who reported the lowest creativity scores, and this may reflect the limited resources of their households which may in turn impact their creativity. This may be an area for the Department of Social Services to consider as it works to enhance the lives of disadvantaged members of society.

The self-reported creativity scores allow areas of creativity where university students claim to be creative to be identified relative to other aspects of creativity. As might be expected, the more academic aspects of creativity are those areas in which students claim to excel, whereas the more hands-on activities - drawing, pottery, carving - were associated with lower creativity scores. Writing a computer programme/app was not an activity in which students reported much creativity. This might be a concern given the constant use of such technology by millennials. It also implies that our university educated millennials are consumers only of such technology and may be unable to adapt or develop it to the workplace. This finding raises the question of the level of success of the "Bahamas Roadmap for Science and Technology" (Bahamas Environment, Science and Technology Commission, 2005). It does not reflect the skills in students which might have been anticipated, even though the importance of technology on national development continues to be stated as a priority (Minnis, 2013).

The potential impact on national development by enhancing creativity can be 
seen from the link between creativity and risk taking associated with investing money in a start-up or one's own business (also see Macko \& Tyszka, 2009), compared to a less risky investment of funds in a bank. Creativity is recognised as being an important characteristic of an entrepreneur (Schmidt, Soper, \& Bernaciak, 2013) and so the education system should do all that it can to encourage creativity. This requires that school systems do not, as some have suggested, kill creativity (Robinson, 2006). This leads to the question as to what changes may be required to the Bahamian school system to enhance student creativity. How can the curriculum allow for risk taking associated with entrepreneurship?

\section{References}

Bahamas Environment, Science, and Technology Commission. (2005). Road map for the advancement of science and technology in the Bahamas. Nassau: BEST Commission. Retrieved from http://www.best.gov.bs/Documents/Road_ Map_new_10.01.06.pdf

Bahamas Information Services. (2016). Public School Scholars Programme providing college opportunities for public school students. Retrieved from http://www.bahamas.gov.bs/wps/portal/pub lic/gov/government/news/

Barell, J. (1995). Teaching for thoughtfulness: Classroom strategies to enhance intellectual development. White Plains, NY: Longman.

Boden, M. A. (1994). Dimensions of creativity. Cambridge, MA: MIT Press.

Carroll, M. A., Fielding, W. J., Brennen, S., \& Hutcheson, S. P. (2016). Rearing violence: Violence toward children at home. In W. J. Fielding, V. C. F. Ballance, \& I. G.
This study has shed light on an area of the country's human capital which is essential for the development of not only the individual but also the nation. It suggests that teachers have an important, yet not singular, role to play in developing the creativity of students. Thus their training, class size and the curriculum need to be aligned so that the creativity of students can flourish.

Given that this study was limited to participants who have progressed to university, in order to be more instructive, there is a need to widen the scope of the research to include a wider cross-section of persons to test the robustness of the findings.

Strachan (Eds.) Violence in The Bahamas (pp. 31-62). Nassau: University of The Bahamas.

Changwong, K., Sukkamart, A., \& Sisan, B. (2018). Enhancing Thai high school student critical thinking capability: A new learning management model. Asia-Pacific Social Science Review, 18(1), 175-183. Retrieved from http://apssr.com/wpcontent/uploads/2018/06/RB-5.pdf

Collie-Patterson, J. M. (2008). The national average is D: Who is to blame? College of The Bahamas Research Journal, 14, 28-37. https://doi.org/10.15362/ijbs.v14i0.102

Darn, S. (2006). Thinking outside the teacher's box. Retrieved from https://files.eric.ed.gov/fulltext/ED493025. pdf

Dean, B. (2018, November 28). Bahamas needs new, creative people. We should recruit productive types from around the world to boost population, drive innovation. Nassau Guardian. Retrieved from 
https://thenassauguardian.com/2018/11/28/ bahamas-needs-new-creative-people/

Eisenman, R. (2008). Malevolent creativity in criminals. Creativity Research Journal, 20(2), 116-119. https://doi.org/10.1080/1040041080205946 5

Fang, Z., Xu, X., Grant, L. W., Stronge, J. H., \& Ward, T. J. (2016). National culture, creativity, and productivity: What's the relationship with student achievement? Creativity Research Journal, 28(4), 395406. https://doi.org/10.1080/10400419.2016.122 9976

Fielding, W. J., Ballance, V. C. F., \& Strachan, I. G. (Eds.). (2016). Violence in The Bahamas. Nassau: University of The Bahamas.

Foster, R. N. (2015). What is creativity? Yale Insights. Retrieved from https://insights.som.yale.edu/insights/whatis-creativity

Geist, E., \& Hohn, J. (2009). Encouraging creativity in the face of administrative convenience: how our schools discourage divergent thinking. Education, 130(1), 141150. Retrieved from http://search.ebscohost.com/login.aspx?dir ect=true \&db=a9h\&AN=44016931\&site $=e$ ds-live

Goodman, S. (2015). Fuel creativity in the classroom with divergent thinking.

Retrieved from https://www.edutopia.org/blog/fuelingcreativity-through-divergent-thinkingclassroom-stacey-goodman

Guncer, B., \& Oral, G. (1993). Relationship between creativity and nonconformity to school discipline as perceived by teachers. Journal of Instructional Psychology, 20(3), 208-214.
Johnson, P. (2016).Violence in school. In W. J. Fielding, V. C. F. Ballance, \& I. G. Strachan (Eds.), Violence in The Bahamas (pp. 113-133). Nassau: University of The Bahamas.

Kaufman, J. C. (2012). Counting the muses: Development of the Kaufman Domains of Creativity Scale (K-DOCS.) Psychology of Aesthetics, Creativity, and the Arts, 6(4), 298-308. https://doi.org/10.1037/a0029751

Macko, A., \& Tyszka, T. (2009). Entrepreneurship and risk taking. Applied Psychology. 58, 469-487. https://doi.org/10.1111/j.14640597.2009.00402.x

MacSuga-Gage, A. S., \& Simonsen, B. (2015). Examining the effects of teacherdirected opportunities to respond on student outcomes: A systematic review of the literature. Education \& Treatment of Children, 38(2), 211-239. https://doi.org/ 10.1353/etc.2015.0009

Minnis, H. (2013, November 4). The new Bahamas: Technological proficiency. Nassau Guardian. Retrieved from https://thenassauguardian.com/2013/11/04/ the-new-bahamas-technologicalproficiency/

Noddings, N. (2013). Standardized curriculum and loss of creativity. Theory Into Practice, 52(3), 210-215. https://doi.org/10.1080/00405841.2013.804 315

Pearson, S. (2018). How to teach kids to think outside the box. Retrieved from https://www.tsc.nsw.edu.au/tscnews/howto-teach-kids-to-think-outside-the-box

Perry, M., \& Collier, D. R. (2018). What counts as creativity in education? An inquiry into the intersections of public, political, and policy discourses. Canadian Journal of Education, 41(1), 24-43.

Retrieved from http://cje- 
rce.ca/journals/volume-41-issue-1/whatcounts-as-creativity-in-education-aninquiry-into-the-intersections-of-publicpolitical-and-policy-discourses/

Robinson, K. (2006). Do schools kill creativity? Technology, entertainment and design lecture. Retrieved from https://www.ted.com/talks/ken_robinson_s ays_schools_kill_creativity

Rudowicz, E. (2003). Creativity and culture: A two way interaction. Scandinavian Journal of Educational Research, 47(3), 273. https://doi.org/10.1080/00313830308602

Schmidt, J. J., Soper, J. C., \& Bernaciak, J. (2013). Creativity in the entrepreneurship program: A survey of the directors of award winning programs. Journal of Entrepreneurship Education, 16, 31-44. Retrieved from https://www.abacademies.org/articles/jeevo 1162013.pdf

Sherin, K. M., Sinacore, J. M., Li, X., Zitter, R. E., \& Shakil, A. (1998). HITS: A short domestic violence screening tool for use in a family practice setting. Family Medicine, 30(7), 508-512. Retrieved from http://www.stfm.org/fmhub/FULLPDF/JU LY AUG98/cram1.pdf

Smith, D. E., \& Mosby, G. (2003). Jamaican child-rearing practices: The role of corporal punishment. Adolescence, 38(150), 369-

381. Available at http://search.ebscohost.com/login.aspx?dir ect $=$ true $\& d b=a 9 h \& A N=11066264 \&$ site $=e$ ds-live

Tan, C. (2006). Creating thinking schools through knowledge and inquiry: The curriculum challenges for Singapore. Curriculum Journal, 17(1), 89-105. https://doi.org/10.1080/0958517060068264 0
Turnquest, A. (2018, February 28). It's time to stop school beatings. The Tribune.

Retrieved from http://www.tribune242.com/news/2018/feb /28/its-time-stop-school-beatings/

United Nations Development Programme. (2012). Caribbean human development report 2012. Human development and the shift to better citizen security. Retrieved from http://www.regionalcentrelacundp.org/en/hdr-caribbean

United Nations System Task Team on the Post-2015 UN Development Agenda. (2015, May). Education and skills for inclusive and sustainable development beyond 2015. New York: UNESCO. Retrieved from http://www.un.org/millenniumgoals/pdf/Th ink\%20Pieces/4_education.pdf

Villalba, E. (2008). On creativity: Towards an understanding of creativity and its measurements. Retrieved from: https://www.researchgate.net/publication/2 42710922_On_Creativity_Towards_an_Un derstanding_of_Creativity_and_its_Measur ements

Wang, M., \& Degol, J. (2014). Staying engaged: Knowledge and research needs in student engagement. Child Development Perspectives, 8(3), 137-143. https://doi.org/10.1111/cdep.12073 